\title{
Defying the stereotype: non-canonical roles of the peptide hormones guanylin and uroguanylin
}

\section{Nirmalya Basu and Sandhya Srikant Visweswariah*}

Department of Molecular Reproduction, Development and Genetics, Indian Institute of Science, Bangalore, India

Edited by:

Regina Pekelmann Markus, University of São Paulo, Brazil

\section{Reviewed by:}

Maristela De Oliveira Poletini,

University of São Paulo, Brazil

Nilberto Robson Falcão Nascimento,

Universidade Estadual do Ceará,

Brazil

\section{*Correspondence:}

Sandhya Srikant Visweswariah,

Department of Molecular

Reproduction, Development and

Genetics, Indian Institute of Science,

Bangalore 560012, India.

e-mail: sandhya@mrdg.iisc.ernet.in
The peptide hormones uroguanylin and guanylin have been traditionally thought to be mediators of fluid-ion homeostasis in the vertebrate intestine. They serve as ligands for receptor guanylyl cyclase C (GC-C), and both receptor and ligands are expressed predominantly in the intestine. Ligand binding to GC-C results in increased cyclic GMP production in the cell which governs downstream signaling. In the last decade, a significant amount of research has unraveled novel functions for this class of peptide hormones, in addition to their action as intestinal secretagogues. An additional receptor for uroguanylin, receptor guanylyl cyclase D, has also been identified. Thus, unconventional roles of these peptides in regulating renal filtration, olfaction, reproduction, and cell proliferation have begun to be elucidated in detail. These varied effects suggest that these peptide hormones act in an autocrine, paracrine as well as endocrine manner to regulate diverse cellular processes.

\section{Keywords: guanylin, uroguanylin, receptor guanylyl cyclase, GC-C, GC-D}

\section{INTRODUCTION}

Nearly two decades ago, in a search for molecules that regulate cyclic GMP (cGMP) levels in the intestine, guanylin was identified as a low molecular weight, acid stable peptide present in rat jejunal extracts (Currie et al., 1992). A year later, uroguanylin was purified from opossum urine and was seen to exhibit a ten-fold higher bio-activity as compared to guanylin (Hamra et al., 1993). Subsequently, guanylin and uroguanylin emerged as key players in intestinal fluid homeostasis, a phenomenon fundamental to the maintenance of gut physiology. Both these regulatory peptides are produced in the enteroendocrine cells of the intestinal mucosa as precursor proteins and are processed to their mature forms by converting enzymes. The biologically active forms of guanylin and uroguanylin have striking similarities in their structure, and contain four conserved cysteines which form disulfide linkages essential for their activity (Forte, 1999).

Guanylyl cyclase C (GC-C) is the receptor that is activated by these peptides. Owing to its apical localization in enterocytes, the extracellular domain of GC-C can bind uroguanylin/guanylin released into the gut lumen, initiating production of the intracellular second messenger, cGMP (Schulz et al., 1990). Cyclic GMP activates the cystic fibrosis transmembrane conductance regulator (CFTR) that serves as a membrane channel, modulating chloride efflux from the enterocytes lining the intestinal tract. This stimulation of electrogenic chloride secretion, concomitant with an inhibition of sodium absorption, leads to a net fluid secretion into the intestinal lumen. Thus, the endogenous peptides, guanylin, and uroguanylin are involved in the regulation of salt and water transport across the intestinal epithelia. These peptides also regulate CFTR-mediated bicarbonate secretion and inhibit $\mathrm{H}^{+}$extrusion by the $\mathrm{Na}^{+} / \mathrm{H}^{+}$exchanger in the small bowel. This helps in the regulation of intestinal $\mathrm{pH}$, thus stimulating the digestion and absorption of food components (Basu et al., 2010).
In addition to maintenance of intestinal fluid balance, guanylin and uroguanylin target the renal tissue, eliciting natriuresis, kaliuresis, and diuresis, along with increasing urinary cGMP levels (Sindic and Schlatter, 2006). Uroguanylin may also influence longterm renal function, since down-regulation of the mRNAs of the $\mathrm{Na}^{+} / \mathrm{K}^{-}$ATPase $\gamma$-subunit and the chloride channel, ClC-K2, is also observed on uroguanylin administration (Carrithers et al., 2004).

The heat-stable enterotoxin (ST) is a structural and functional homolog of uroguanylin/guanylin. Pathogenic strains of E. coli, and other bacteria that produce ST peptides, cause watery diarrhea as a result of the high levels of fluid-ion secretion elicited by ST binding to GC-C present on intestinal epithelial cells (Field et al., 1978). ST is being considered as a vaccine target to combat enterotoxigenic E. coli, of which some strains are endemic in developing nations. Compared to ST, the endogenous peptides are less potent in stimulating fluid-ion secretion, since the affinity of guanylin and uroguanylin for GC-C is 100-fold and 10-fold lower than ST respectively. ST peptides thus represent a form of molecular mimicry wherein enterotoxigenic E. coli exploit normal intestinal physiology for their dissemination.

Recent reports have identified guanylyl cyclase D (GC-D) as an additional receptor for guanylin and uroguanylin. This less characterized peptide receptor has a domain organization similar to that of GC-C, consisting of an extracellular ligand binding domain, a single transmembrane spanning domain, followed by a kinase homology domain linked to a guanylyl cyclase domain. However unlike GC-C, which is expressed in the intestinal epithelia, GC-D is exclusively expressed in a few neurons of the olfactory epithelia. These cells respond to uroguanylin/guanylin by generating action potentials, probably by elevating intracellular levels of cGMP (Zufall and Munger, 2010). Therefore, in addition to a role for uroguanylin and guanylin as hormonal modulators of fluid 
and electrolyte secretion, there may be other physiological functions for the guanylin family of cGMP-regulating peptides, some of which are discussed below.

\section{RENAL FUNCTIONS}

Apart from maintaining fluid balance in the vertebrate intestine, uroguanylin is also involved in the regulation of kidney function and maintenance of sodium ion balance in the body. Both effects prevent the development of hypernatremia in response to a high oral salt load. Intravenous application of uroguanylin in mice stimulated $\mathrm{Na}^{+}, \mathrm{K}^{+}$, and water excretion in the urine, suggesting that uroguanylin, which is also expressed in the kidney, could serve in an endocrine axis that connects the gastrointestinal tract with the kidney for maintenance of ion balance. Thus, uroguanylin has both local intestinal (paracrine) and endocrine functions, forming a potential enteric-renal link to coordinate salt ingestion with natriuresis (Forte, 2003). In support of this evidence, it was observed that mice lacking the uroguanylin gene have increased blood pressure and an impaired capacity to excrete $\mathrm{Na}^{+}$in the urine when salt loads are administered orally. However, intravenous administration of $\mathrm{NaCl}$ to uroguanylin knock-out mice elicits natriuresis equivalent to that of wild-type animals (Lorenz et al., 2003). Increased dietary intake of $\mathrm{NaCl}$ results in increased uroguanylin expression in the intestine and kidney, implicating both endocrine and paracrine/autocrine actions of uroguanylin in regulation of tubular signaling mechanisms that govern renal sodium transport (Carrithers et al., 2000).

A recent report has suggested that circulating plasma prouroguanylin, the precursor of uroguanylin, may mediate entero-renal signaling. Prouroguanylin is released by the enteroendocrine cells of the intestine in response to a salty meal and is converted to uroguanylin in the kidney, thereby eliciting "postprandial-natriuresis" (Moss et al., 2008; Qian et al., 2008). This is in line with a report that a high salt diet primes the kidney for an enhanced response to uroguanylin (Fonteles et al., 2009).

GC-C knock-out mice have normal blood pressure and renal sodium excretion, but do not exhibit intestinal secretion in response to ST peptides and uroguanylin/guanylin. Moreover, when uroguanylin, guanylin, or ST peptides are administered intravenously to GC-C knock-out mice, they elicit saluretic and diuretic responses, quantitatively equal to that of wild-type mice (Carrithers et al., 2004). Based on the independent phenotypes of uroguanylin and GC-C knock-out mice, it can be suggested that regulation of renal sodium transport is not mediated by GC-C, but through a receptor for uroguanylin whose identity is as yet unknown, and may be coupled to a G-protein (Sindice et al., 2002).

\section{OLFACTORY FUNCTIONS}

The neurons of main olfactory epithelia (MOE) are responsible for sensing a myriad of odors. Canonical olfactory sensory neurons act through odorant receptors and generation of cyclic AMP (cAMP), which binds cyclic nucleotide gated (CNG) channels leading to neuronal membrane depolarization. However, recent research has shown that the cAMP-mediated excitatory pathway is not the lone signaling pathway operating in the MOE. A sub-set of these neurons which express GC-D are suspected to transduce the signal of olfaction in a cAMP-independent manner, as opposed to that seen in the rest of the olfactory epithelia (Fulle et al., 1995). These cells are devoid of the cAMP signaling machinery involving the odorant receptors, namely, $\mathrm{G} \alpha_{\text {olf }}$, type III adenylyl cyclase, the cAMP-dependent phosphodiesterase (PDE4A) and the cAMP-responsive CNG channel subunits, CNGA2 and CNGB1b. On the other hand, these cells express a cGMP-specific CNG channel subunit CNGA3, and a cGMP-dependent phosphodiesterase (PDE2) in addition to GC-D, highlighting the role of cGMP in the physiology of these neurons (Meyer et al., 2000). The axons of these GC-D neurons impinge on the "necklace glomeruli" which reside between the main and the accessory olfactory bulb of mice (Leinders-Zufall et al., 2007).

Through extensive gene-targeting studies in mice, LeindersZufall et al. (2007) demonstrated that these neurons respond to uroguanylin and guanylin in a cGMP-dependent manner to induce formation of action potentials in the MOE. Response to these urinary peptides is specific to the GC-D neurons, and the presence of GC-D has been shown to be crucial for maintenance of normal afferent activity, as well as basal activity, of the necklace glomeruli. GC-D knock-out mice develop the necklace glomeruli but do not respond to the peptide hormones, and have low afferent activity in these neurons (Leinders-Zufall et al., 2007). The GC-D neurons express uroguanylin, which can act in an autocrine/paracrine manner, but this stimulus is insufficient to maintain normal afferent activity in these cells which requires stimuli from the external environment. Therefore, uroguanylin may also act as a social signal and communicate information about food. Uroguanylin levels in the urine rise postprandially, and this may translate to specific chemosensory cues about availability or quantity of food present in the environment (Munger et al., 2010). Recent evidence shows that GC-D containing neurons can also detect and respond to $\mathrm{CO}_{2}$ and bicarbonate which are volatile signals $(\mathrm{Hu}$ et al., 2007; Sun et al., 2009). Thus, a sub-population of the MOE responds to urinary uroguanylin and guanylin and forms a unique cGMP-dependent chemodetection system (Figure 1).

\section{CELL CYTOSTATIC FUNCTIONS}

The intestinal epithelium undergoes waves of proliferation, migration, differentiation, and apoptosis driven by multipotent stem cells. Cyclic GMP has emerged as an important regulator of this process, although the molecular mechanisms mediating this activity are still not clear. The cGMP signal transduction pathway activated by guanylin and uroguanylin appears to help in regulating the turnover of epithelial cells, and maintenance of homeostasis of the intestinal mucosa. The expression of uroguanylin and guanylin is markedly reduced in colon carcinoma, in stark contrast to GC-C, whose expression remains comparable to that seen in normal colonic mucosa (Shailubhai et al., 2000). This has led to the emergence of GC-C as a marker for metastatic colon carcinoma (Carrithers et al., 1996).

In a seminal study, Pitari et al. (2001) demonstrated that the endogenous agonists of GC-C (uroguanylin/guanylin) play a role in regulating the balance between epithelial proliferation and differentiation in the normal intestine, and regulate cell cycle progression. This effect was dependent upon production of cGMP via GC-C and release of intracellular $\mathrm{Ca}^{2+}$ (Pitari et al., 2001). 


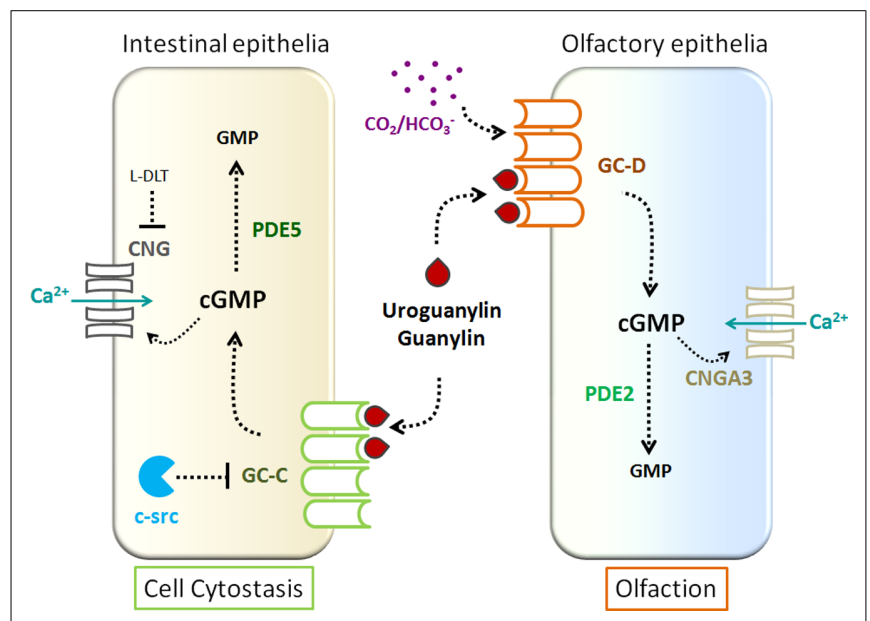

FIGURE 1 | Non-canonical signaling by the guanylin and uroguanylin family of peptide hormones. Binding of guanylin and uroguanylin to GC-C in the intestinal epithelial cell results in an increase in cGMP levels. Intracellular CGMP levels are reduced by the action of PDE5, which cleaves cGMP to form 5'-GMP. Cyclic GMP can act directly on CNG channels to increase cellular $\mathrm{Ca}^{2+}$ levels, resulting in colon cell cytostasis. This process is attenuated by the action of cis---diltiazem (L-DLT), a CNG channel inhibitor. The tyrosine kinase c-src which is frequently found to be activated in colorectal carcinomas, phosphorylates and inhibits GC-C activity, thereby reducing the anti-tumorigenic effects induced by guanylin/uroguanylin/ST peptides. In olfactory epithelia, uroguanylin/guanylin is recognized by GC-D expressed in a sub-set of neurons and evoke action potentials. These neurons also fire in response to $\mathrm{CO}_{2} / \mathrm{HCO}_{3}^{-}$. Hydrolysis of cGMP in these cells is thought to be mediated by PDE2. The renal effects of uroguanylin have been detailed in an earlier review, and are not shown in this figure (Sindic and Schlatter, 2006).

This suggests that the anti-proliferative action of GC-C agonists operate via regulation of $\mathrm{Ca}^{2+}$ influx through $\mathrm{CNG}$ channels, with $\mathrm{Ca}^{2+}$ serving as the third messenger in the signaling cascade, linking GC-C at the cell surface to regulation of proliferation in the nucleus. Guanylin knock-out mice show increased crypt depth and a higher number of proliferating cells, reiterating the role of this molecule in regulating intestinal crypt biology (Currie et al., 1992).

As with all biological phenomena, cell cycle regulation mediated by GC-C is under strict regulation. One mechanism that has been described recently is via the c-src kinase, which phosphorylates and thereby attenuates ligand-mediated activation of GC-C. Colon carcinoma cells usually have enhanced c-src activity and therefore can effectively bypass the cytostatic effects of uroguanylin (Basu et al., 2009). Prolonged GC-C stimulation activates a cGMP-regulated, cGMP-specific phosphodiesterase 5 (PDE5), which lowers intracellular cGMP levels, and in turn affects $\mathrm{Ca}^{2+}$ influx through CNG channels (Pitari et al., 2005). Thus, these negative feedback mechanisms in cGMP-signaling help shape the duration of agonist-induced cytostasis.

Thus, GC-C and its endogenous ligands guanylin/uroguanylin, comprise an integrated paracrine mechanism regulating cryptvillus homeostasis by maintaining the balance between epithelial cell proliferation and differentiation. Uroguanylin and guanylin have also been found to be expressed in pancreatic cells and exert a similar cytostatic effect on pancreatic cancer cells, proving that the uroguanylin/GC-C/cGMP axis may be a generalized anti-proliferative mechanism utilized by multiple organ systems (Kloeters et al., 2008).

Colon cancer is one of the leading causes of cancer-associated mortality in developed countries, but its incidence is relatively low in underdeveloped and developing countries. A common epidemiological characteristic of these colon cancer-spared regions is the prevalence of enterotoxigenic E. coli. Periodic infections with ST producing bacteria in the intestine may elicit a beneficial therapeutic action for individuals in developing nations. The action of the ST peptides could prevent proliferation at relatively early stages of tumor growth, thus providing resistance to intestinal neoplasia (Pitari et al., 2003).

\section{REPRODUCTIVE FUNCTIONS}

Even though GC-C is predominantly expressed in the intestinal epithelia, extra-intestinal sites of expression have been discovered, suggesting that signaling mediated by GC-C and its ligands may play a role in extra-intestinal tissue as well. The mammalian testis and ovary both display the presence of the GC-C transcript (Jaleel et al., 2002). However its role in these tissues is unclear. One can speculate that GC-C regulates fluid-ion homeostasis in the ductal systems of these glandular tissues.

Although the effect of NO on cGMP accumulation and smooth muscle relaxation has been well characterized, the function of cGMP produced by receptor GCs is poorly understood. Cyclic GMP accumulation in the pregnant myometrium is able to relax oxytocin-induced contractions. This response was elicited in response to uroguanylin and was not dependent on the NOsensitive soluble guanylyl cyclases, pointing toward a possible compartmentalization of the cGMP signal. Indeed, uroguanylin and GC-C are co-expressed in the uterus, and GC-C is enriched in the lipid raft fraction of myocytes (Buxton et al., 2010). Therefore, it is possible that smooth muscle relaxation in uterine tissue is elicited by GC-C and its ligands. Similarly, uroguanylin has been shown to elevate cGMP levels in human corpora cavernosa, resulting in its relaxation, leading to the possibility of targeting receptor guanylyl cyclases for the treatment of erectile dysfunction (Sousa et al., 2010).

The rat epididymis revealed the presence of differentially glycosylated forms of GC-C, and epididymal minces responded to uroguanylin by elevation of cGMP levels (Jaleel et al., 2002). The function of this signaling pathway in the epididymis is open to speculation, since the reproductive capacity of GC-C knock-out animals is not altered.

\section{CONCLUSION}

We have attempted to highlight here recent findings on the diverse roles of guanylin and uroguanylin in vertebrate physiology. These peptides, as well as their receptor, GC-C, are evolutionarily conserved. Orthologs are found in fishes, amphibians, reptiles, and birds, indicating the need for this cGMP-signaling machinery in higher eukaryotes (Krause et al., 1997; Yuge et al., 2003). While early research focused on the importance of the ligands and the receptor in intestinal physiology, it is clear that their roles are varied and distinct in different tissues. We anticipate a greater 
awareness of the non-classical roles that GC-C and its ligands may play in vertebrate physiology in coming years, and suggest that some effects mediated by them may turn out to be cGMPindependent. For example, novel receptors for these peptides may be identified that are not coupled to a guanylyl cyclase, and the complex domain organization of GC-C may allow the formation of intracellular signaling complexes that elicit responses independent of the guanylyl cyclase domain. Exciting times indeed lie ahead.

\section{REFERENCES}

Basu, N., Arshad, N., and Visweswariah, S. S. (2010). Receptor guanylyl cyclase C (GC-C): regulation and signal transduction. Mol. Cell. Biochem. 334, 67-80.

Basu, N., Bhandari, R., Natarajan, V. T., and Visweswariah, S. S. (2009). Cross talk between receptor guanylyl cyclase $\mathrm{C}$ and c-src tyrosine kinase regulates colon cancer cell cytostasis. Mol. Cell. Biol. 29, 5277-5289.

Buxton, I. L., Milton, D., Barnett, S. D., and Tichenor, S. D. (2010). Agonistspecific compartmentation of cGMP action in myometrium. J. Pharmacol. Exp. Ther. 335, 256-263.

Carrithers, S. L., Barber, M. T., Biswas, S., Parkinson, S. J., Park, P. K., Goldstein, S. D., and Waldman, S. A. (1996). Guanylyl cyclase C is a selective marker for metastatic colorectal tumors in human extraintestinal tissues. Proc. Natl. Acad. Sci. U.S.A. 93, 14827-14832.

Carrithers, S. L., Ott, C. E., Hill, M. J., Johnson, B. R., Cai, W., Chang, J. J., Shah, R. G., Sun, C., Mann, E. A., Fonteles, M. C., Forte, L. R., Jackson, B. A., Giannella, R. A., and Greenberg, R. N. (2004). Guanylin and uroguanylin induce natriuresis in mice lacking guanylyl cyclase-C receptor. Kidney Int. 65, 40-53.

Carrithers, S. L., Taylor, B., Cai, W. Y., Johnson, B. R., Ott, C. E., Greenberg, R. N., and Jackson, B. A. (2000). Guanylyl cyclase-C receptor mRNA distribution along the rat nephron. Regul. Pept. 95, 65-74.

Currie, M. G., Fok, K. F., Kato, J., Moore, R. J., Hamra, F. K., Duffin, K. L., and Smith, C. E. (1992). Guanylin: an endogenous activator of intestinal guanylate cyclase. Proc. Natl. Acad. Sci. U.S.A. 89, 947-951.

Field, M., Graf, L. H. Jr., Laird, W. J., and Smith, P. L. (1978). Heatstable enterotoxin of Escherichia coli: in vitro effects on guanylate cyclase activity, cyclic GMP concentration, and ion transport in small intestine. Proc. Natl. Acad. Sci. U.S.A. 75, 2800-2804.
Fonteles, M. C., Havt, A., Prata, R. B., Prata, P. H., Monteiro, H. S., Lima, A. A., Jorge, A. R., Santos, C. F., Greenberg, R. N., and Nascimento, N. R. (2009). High-salt intake primes the rat kidney to respond to a subthreshold uroguanylin dose during ex vivo renal perfusion. Regul. Pept. 158, 6-13.

Forte, L. R. (1999). Guanylin regulatory peptides: structures, biological activities mediated by cyclic GMP and pathobiology. Regul. Pept. 81, 25-39.

Forte, L. R. (2003). A novel role for uroguanylin in the regulation of sodium balance. J. Clin. Invest. 112, 1138-1141.

Fulle, H. J., Vassar, R., Foster, D. C., Yang, R. B., Axel, R., and Garbers, D. L. (1995). A receptor guanylyl cyclase expressed specifically in olfactory sensory neurons. Proc. Natl. Acad. Sci. U.S.A. 92, 3571-3575.

Hamra, F. K., Forte, L. R., Eber, S. L., Pidhorodeckyj, N. V., Krause, W. J., Freeman, R. H., Chin, D. T., Tompkins, J. A., Fok, K. F., Smith, C. E., Duffin, K. L., Siegel, N. R., and Currie, M. G. (1993). Uroguanylin: structure and activity of a second endogenous peptide that stimulates intestinal guanylate cyclase. Proc. Natl. Acad. Sci. U.S.A. 90, 10464-10468.

Hu, J., Zhong, C., Ding, C., Chi, Q. Walz, A., Mombaerts, P., Matsunami, H., and Luo, M. (2007). Detection of near-atmospheric concentrations of $\mathrm{CO} 2$ by an olfactory subsystem in the mouse. Science 317, 953-957.

Jaleel, M., London, R. M., Eber, S. L., Forte, L. R., and Visweswariah, S. S. (2002). Expression of the receptor guanylyl cyclase $\mathrm{C}$ and its ligands in reproductive tissues of the rat: a potential role for a novel signaling pathway in the epididymis. Biol. Reprod. 67, 1975-1980.

Kloeters, O., Friess, H., Giese, N., Buechler, M. W., Cetin, Y., and Kulaksiz, H. (2008). Uroguanylin inhibits proliferation of pancreatic cancer cells. Scand. J. Gastroenterol. 43, 447-455.

Krause, W. J., London, R. M., Freeman, R. H., and Forte, L. R. (1997). The

\section{ACKNOWLEDGMENTS}

The authors would like to thank past and present members of the laboratory for providing a stimulating environment at all times, and Anisha Zaveri for critical reading of the manuscript. Nirmalya Basu has been provided fellowships by the Indian Institute of Science and the Council for Scientific and Industrial Research, Government of India. We also acknowledge the Departments of Science and Technology, and Biotechnology, and the Indian Council for Medical Research, for funding support.

guanylin and uroguanylin peptide hormones and their receptors. Acta Anat (Basel) 160, 213-231.

Leinders-Zufall, T., Cockerham, R. E., Michalakis, S., Biel, M., Garbers, D. L., Reed, R. R., Zufall, F., and Munger, S. D. (2007). Contribution of the receptor guanylyl cyclase GC-D to chemosensory function in the olfactory epithelium. Proc. Natl. Acad. Sci. U.S.A. 104, 14507-14512.

Lorenz, J. N., Nieman, M., Sabo, J., Sanford, L. P., Hawkins, J. A., Elitsur, N., Gawenis, L. R., Clarke, L. L., and Cohen, M. B. (2003). Uroguanylin knockout mice have increased blood pressure and impaired natriuretic response to enteral $\mathrm{NaCl}$ load. J. Clin. Invest. 112, 1244-1254.

Meyer, M. R., Angele, A., Kremmer, E., Kaupp, U. B., and Muller, F. (2000). A cGMP-signaling pathway in a subset of olfactory sensory neurons. Proc. Natl. Acad. Sci. U.S.A. 97, 10595-10600.

Moss, N. G., Fellner, R. C., Qian, X., Yu, S. J., Li, Z., Nakazato, M., and Goy, M. F. (2008). Uroguanylin, an intestinal natriuretic peptide, is delivered to the kidney as an unprocessed propeptide. Endocrinology 149, 4486-4498.

Munger, S. D., Leinders-Zufall, T., Mcdougall, L. M., Cockerham, R. E., Schmid, A., Wandernoth, P., Wennemuth, G., Biel, M., Zufall, F., and Kelliher, K. R. (2010). An olfactory subsystem that detects carbon disulfide and mediates foodrelated social learning. Curr. Biol. 20, 1438-1444.

Pitari, G. M., Baksh, R. I., Harris, D. M., Li, P., Kazerounian, S., and Waldman, S. A. (2005). Interruption of homologous desensitization in cyclic guanosine $3^{\prime}, 5^{\prime}$ monophosphate signaling restores colon cancer cytostasis by bacterial enterotoxins. Cancer Res. 65, 11129-11135.

Pitari, G. M., Di Guglielmo, M. D., Park, J., Schulz, S., and Waldman, S. A. (2001). Guanylyl cyclase C agonists regulate progression through the cell cycle ofhuman colon carcinoma cells. Proc. Natl. Acad. Sci. U.S.A. 98, 7846-7851.

Pitari, G. M., Zingman, L. V., Hodgson, D. M., Alekseev, A. E., Kazerounian, S., Bienengraeber, M., Hajnoczky, G., Terzic, A., and Waldman, S. A. (2003). Bacterial enterotoxins are associated with resistance to colon cancer. Proc. Natl. Acad. Sci. U.S.A. 100, 2695-2699.

Qian, X., Moss, N. G., Fellner, R. C., and Goy, M. F. (2008). Circulating prouroguanylin is processed to its active natriuretic form exclusively within the renal tubules. Endocrinology 149, 4499-4509.

Schulz, S., Green, C. K., Yuen, P. S., and Garbers, D. L. (1990). Guanylyl cyclase is a heat-stable enterotoxin receptor. Cell 63, 941-948.

Shailubhai, K., Yu, H. H., Karunanandaa, K., Wang, J. Y., Eber, S. L., Wang, Y., Joo, N. S., Kim, H. D., Miedema, B. W., Abbas, S. Z., Boddupalli, S. S., Currie, M. G., and Forte, L. R. (2000). Uroguanylin treatment suppresses polyp formation in the $\operatorname{Apc}(\mathrm{Min} /+$ mouse and induces apoptosis in human colon adenocarcinoma cells via cyclic GMP. Cancer Res. 60, 5151-5157.

Sindic, A., and Schlatter, E. (2006). Cellular effects of guanylin and uroguanylin. J. Am. Soc. Nephrol. 17, 607-616.

Sindice, A., Basoglu, C., Cerci, A., Hirsch, J. R., Potthast, R., Kuhn, M., Ghanekar, Y., Visweswariah, S. S., and Schlatter, E. (2002). Guanylin, uroguanylin, and heatstable euterotoxin activate guanylate cyclase $\mathrm{C}$ and/or a pertussis toxinsensitive $G$ protein in human proximal tubule cells. J. Biol. Chem. 277, 17758-17764.

Sousa, C. M., Havt, A., Santos, C. F., Arnaud-Batista, F. J., Cunha, K. M., Cerqueira, J. B., Fonteles, M. C., and Nascimento, N. R. (2010). The relaxation induced by uroguanylin and the expression of natriuretic peptide receptors in human corpora cavernosa. J. Sex. Med. 7, 3610-3619. 
Sun, L., Wang, H., Hu, J., Han, J., Matsunami, H., and Luo, M. (2009). Guanylyl cyclase-D in the olfactory $\mathrm{CO} 2$ neurons is activated by bicarbonate. Proc. Natl. Acad. Sci. U.S.A. 106, 2041-2046.

Yuge, S., Inoue, K., Hyodo, S., and Takei, Y. (2003). A novel guanylin family (guanylin, uroguanylin, and renoguanylin) in eels: possible osmoregulatory hormones in intestine and kidney. J. Biol. Chem. 278, 22726-22733.

Zufall, F., and Munger, S. D. (2010). Receptor guanylyl cyclases in mammalian olfactory function. Mol. Cell. Biochem. 334, 191-197.

Conflict of Interest Statement: The authors declare that the research was conducted in the absence of any commercial or financial relationships that could be construed as a potential conflict of interest.

Received: 24 April 2011; accepted: 26 May 2011; published online: 15 June 2011.

Citation: Basu $N$ and Visweswariah SS (2011) Defying the stereotype: non-canonical roles of the peptide hormones guanylin and uroguanylin. Front. Endocrin. 2:14. doi: 10.3389/fendo.2011.00014
This article was submitted to Frontiers in Cellular Endocrinology, a specialty of Frontiers in Endocrinology.

Copyright (C) 2011 Basu and Visweswariah. This is an open-access article subject to a non-exclusive license between the authors and Frontiers Media $S A$, which permits use, distribution and reproduction in other forums, provided the original authors and source are credited and other Frontiers conditions are complied with. 